\title{
Article \\ Hollow-Shell-Structured Mesoporous Silica-Supported Palladium Catalyst for an Efficient Suzuki-Miyaura Cross-Coupling Reaction
}

\author{
Abdulelah Taher Ali Mohammed, Lijian Wang, Ronghua Jin, Guohua Liu and Chunxia Tan * \\ Key Laboratory of Resource Chemistry of Ministry of Education, Shanghai Key Laboratory of Rare Earth \\ Functional Materials, Shanghai Normal University, Shanghai 200234, China; ay201398@gmail.com (A.T.A.M.); \\ 1000479877@smail.shnu.edu.cn (L.W.); rhjin@shnu.edu.cn (R.J.); ghliu@shnu.edu.cn (G.L.) \\ * Correspondence: tanchx@shnu.edu.cn; Tel.: +86-21-6432-2280; Fax: +86-21-6432-2511
}

Citation: Mohammed, A.T.A.; Wang,

L.; Jin, R.; Liu, G.; Tan, C.

Hollow-Shell-Structured Mesoporous Silica-Supported Palladium Catalyst for an Efficient Suzuki-Miyaura Cross-Coupling Reaction. Catalysts 2021, 11, 582. https://doi.org/ $10.3390 /$ catal11050582

Academic Editor: Hiroto Yoshida

Received: 30 March 2021

Accepted: 29 April 2021

Published: 30 April 2021

Publisher's Note: MDPI stays neutral with regard to jurisdictional claims in published maps and institutional affiliations.

Copyright: (c) 2021 by the authors. Licensee MDPI, Basel, Switzerland. This article is an open access article distributed under the terms and conditions of the Creative Commons Attribution (CC BY) license (https:// creativecommons.org/licenses/by/ $4.0 /)$.

\begin{abstract}
The construction of a high stability heterogeneous catalyst for privileged common catalysis is a benefit in regard to reuse and separation. Herein, a palladium diphenylphosphine-based hollow-shell-structured mesoporous catalyst (HS@PdPPh $@$ @MSN) was prepared by immobilizing bis((diphenylphosphino)ethyltriethoxysilane)palladium acetate onto the inner wall of a mesoporous organicsilicane hollow shell, whose surface was protected by a $-\mathrm{Si}(\mathrm{Me})_{3}$ group. Electron microscopies confirmed its hollow-shell-structure, and structural analyses and characterizations revealed its welldefined single-site active species within the silicate network. As presented in this study, the newly constructed HS@PdPPh $@$ @MSN enabled an efficient Suzuki-Miyaura cross-coupling reaction for varieties of substrates with up to $95 \%$ yield in mild conditions. Meanwhile, it could be reused at least five times with good activity, indicating its excellent stability and recyclability. Furthermore, the cost-effective and easily synthesized HS@PdPPh $\mathbf{2} @ \mathbf{M S N}$ made it a good candidate for employment in fine chemical engineering.
\end{abstract}

Keywords: hollow-shell; mesoporous silica; Suzuki-Miyaura cross-coupling; palladium catalyst

\section{Introduction}

The development of specific porous materials for improving the atom-effectiveness of the privileged catalysts is an important issue in organic synthesis [1-3]. Palladium catalysts are well-known for their high activity in coupling reactions [4-7], especially for the Suzuki-Miyaura cross-coupling reaction, which is an essential method to construct biaryls in pharmaceuticals, polymers, and agrochemical compounds [8-12]. Currently, considerable studies have been processed in exploiting palladium-based homogeneous [13-22] and/or heterogeneous catalysts [23-32] with high activities and universals for the ranges of the substrate in synthesis biaryls. However, the palladium-based homogeneous catalysts are always expensive and difficult to separate from the reaction limiting their application in the industry [22]. In comparison, palladium-based heterogeneous catalysts, prepared by immobilizing catalytic activity sites on supports such as silica [23-25], supramolecular [26,27], polymers [28-30], and metal-organic porous materials [31,32], have shown excellent advantages in stability and recyclability, whereas some of these heterogeneous Pd catalysts show a lower activity due to the impeding access between catalytic-active sites and substrates compared to their corresponding homogeneous species [33]. Therefore, exploiting suitable methods and specific materials to construct efficient palladium-based heterogeneous catalysts has no doubt arouse a research interest in recent years.

Hollow-shell structures are distinctive woid shell configuration materials [34-37]. In recent years, they have attracted tremendous interest in nanoreactors [38], biomedicine [39], lithium-ion batteries [40-42], and photocatalysis [43]. Benefiting from the hierarchical porous structures of the shell, the confined functionality of the inner shell showed good 
substance-loading properties, as well as faster mass diffusion [16]. Thus, the affinity of the substrates and the catalytic-active site improved within hollow shells, making them good candidates as highly active catalytic materials. Significantly, the immobilization of the catalytic active site onto the specific skeleton mesoporous silica materials was extensively employed for improving its activity and recyclability [44-46]. For example, the silica gel-supported N-heterocyclic carbene-Pd (NHC-Pd) [25] and the core-shell hybrid $\mathrm{Fe}_{3} \mathrm{O}_{4} @ \mathrm{SiO}_{2} @ \mathrm{Pd}$ catalyst [24,47] compared to those reported mesoporous silica-supported $\mathrm{Pd}$ catalysts, the functionality of the hollow in the shell-structure has rarely been studied in regard to Suzuki-Miyamura cross-coupling reactions. By protecting the outer wall of the hollow shells by specific hydrophobic groups, the catalytically active sites could be accurately located on the inner wall, while the hollow provided a relatively homogeneous space that was isolated by a permeable shell, thereby providing a promising platform for heterogeneous catalysis application $[48,49]$.

Inspired by the unique hollow-shell structure and high stability of porous organosilaneassisted materials, we modified the inner wall with 2-(diphenylphosphino)ethyltriethoxysilane and cross-linked the derivatives diphenylphosphine with $\mathrm{Pd}(\mathrm{OAc})_{2}$ to construct hollowshell-structured mesoporous silica-based heterogeneous catalyst HS@PdPPh $@ \mathrm{MSN}$. The structural analyses and characterizations indicated the well-defined single-site $\mathrm{Pd}^{2+}$ active species within the inner shell, and the afforded HS@PdPPh ${ }_{2} @ \mathrm{MSN}$ exhibited excellent catalytic capacity and activity compared to those of related homogeneous controls and other core/hollow shell solid catalysts. Furthermore, $\mathrm{HS} @ \mathrm{PdPPh}_{2} @ \mathrm{MSN}$ possessed excellent stability and recyclability, which could be reused at least five times without a significant loss of activity. The easy and cost-effective construction of this heterogeneous HS@PdPPh $@ \mathrm{PMSN}_{2}$ made it a candidate for applications in fine chemical engineering.

\section{Results and Discussion}

\subsection{Synthesis and Structural Characterization of the Hollow-Shell Catalyst}

Hollow-shell-structured $\left(\mathrm{PPh}_{2}\right)_{2} \mathrm{Pd}(\mathrm{OAc})_{2}$-functionalized mesoporous silica nanoparticles, abbreviated as HS@PdPPh $@ M S N(3)$, were synthesized through a simple postgrafting-complexation three-step procedure, as shown in Scheme 1. The first step was the co-condensation of tetraethoxysilane (TEOS) and 1,2-bis(triethoxysilyl)ethane, followed by the modification of hexamethyldisilazane (HMDS) leading to silylated core-

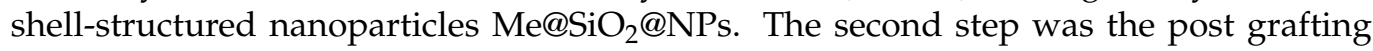
of diphenyl(2-(triethoxysilyl)ethyl)phosphane within the inner surface of the silylated Me@HS@MSN (1), which was obtained by an etching process in toluene for $12 \mathrm{~h}$ under refluxing condition. The third step was the direct complexation of the immobilized diphenyl(2-(triethoxysilyl)ethyl)phosphane with $\mathrm{Pd}(\mathrm{OAc})_{2}$ in the cavity of the hollow-shellstructured mesoporous silica and producing of the coarse catalyst 3 , which was subjected to a Soxhlet extraction to remove the unreactive materials providing its pure form as a gray powder. For comparison, an analog (catalyst $3^{\prime}$ ) of catalyst 3 , which was unprotected by hexamethyldisilazane, was also prepared by a similar procedure (see Supplementary Information in the Experimental Section, and Figures S1-S2). The thermal gravimetric (TG) analysis revealed that the $\mathrm{PdPPh}_{2}$-loadings in catalyst 3 was $97.47 \mathrm{mg}(0.92 \mathrm{mmol})$ per gram catalyst, which was in accordance with the mole amount of Pd-loadings $(1.03 \mathrm{mmol}$ $(110.6 \mathrm{mg}$ ) per gram catalyst 3 ) detected by using an inductively coupled plasma optical emission spectrometer (ICP-OES) analysis.

The solid-state ${ }^{13} \mathrm{C}$ cross-polarization (CP)/magic angle spinning (MAS) NMR spectroscopy was collected to confirm the incorporation of the $\left(\mathrm{PPh}_{2}\right)_{2} \mathrm{Pd}(\mathrm{OAc})_{2}$-functionality within the inner sphere of the hollow shell of three. As shown in Figure 1, the strong carbon signals around $5.6 \mathrm{ppm}$ belonged to the $-\mathrm{SiCH}_{2} \mathrm{CH}_{2} \mathrm{Si}-$ groups for the ethylene-bridged moiety in catalyst 3, suggesting its ethylene-bridged network of the organosilicate shell. Especially, the characteristic peaks at 26.9 and $188.5-174.3 \mathrm{ppm}$ for the carbon atoms of $-\mathrm{CH}_{2} \mathrm{P}$ and $-\mathrm{PC}_{6} \mathrm{H}_{5}$ groups were presented in catalyst 3 , similar to those of its homogeneous counterpart [50]. Further, in the spectrum of three, the strong signals for the carbon atoms 
of the aromatic ring could be observed clearly, while all these peaks were absent in the spectrum of one, revealing that three had the same well-defined single-site active species as its homogeneous counterpart. Moreover, its solid-state ${ }^{31}$ P CP MAS spectrum (Figure 2) also demonstrated the same well-defined single-site active species as its homogeneous counterpart [51].

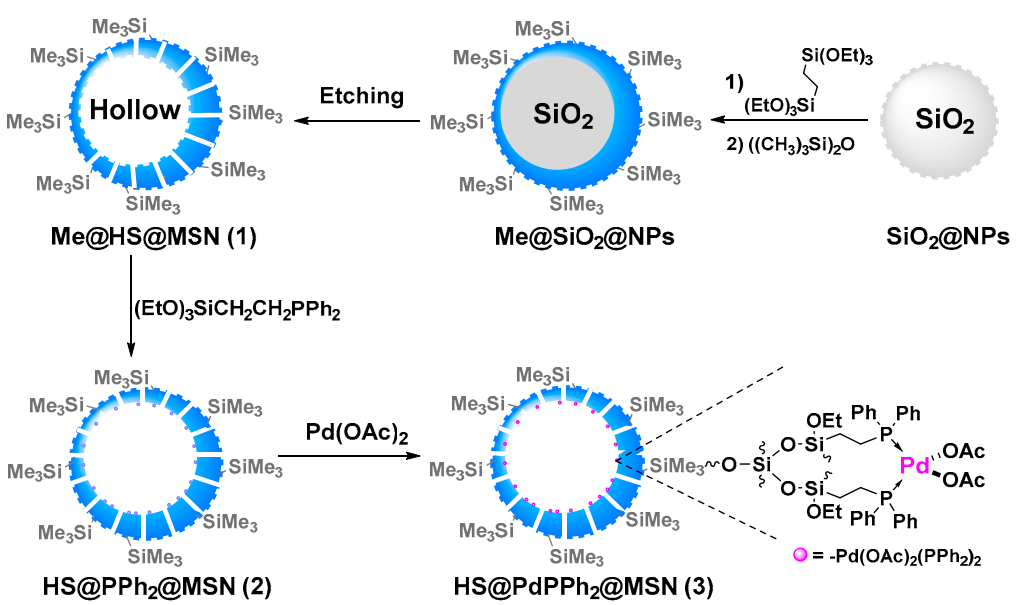

Scheme 1. Preparation of catalyst 3.
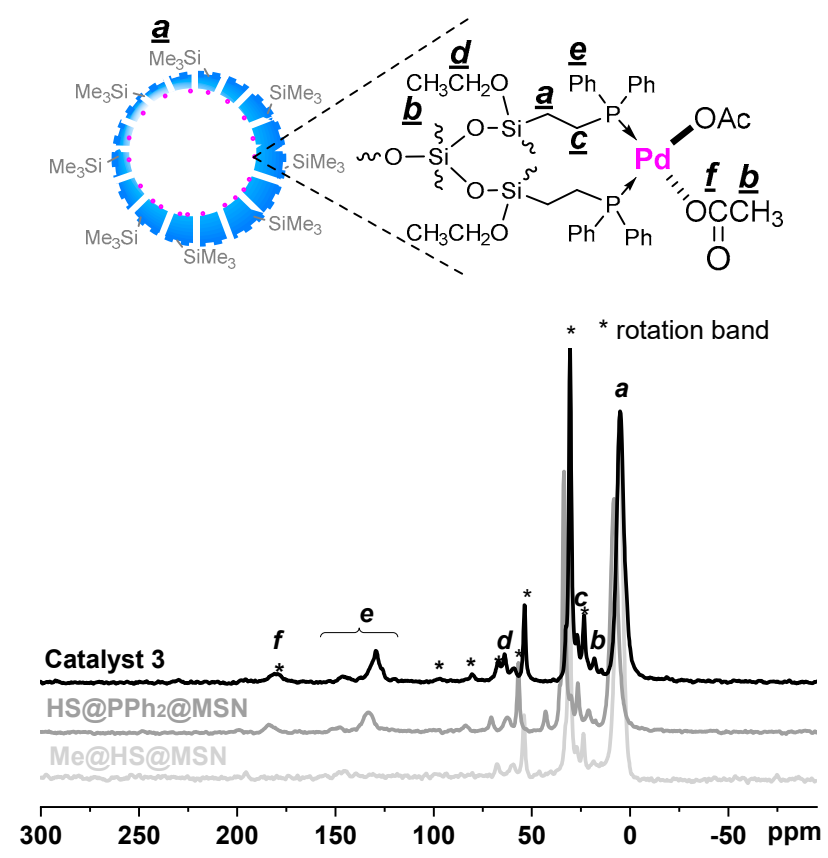

Figure 1. The solidstate ${ }^{13} \mathrm{C} C \mathrm{CP}$ MAS NMR spectra of one and catalyst 3.

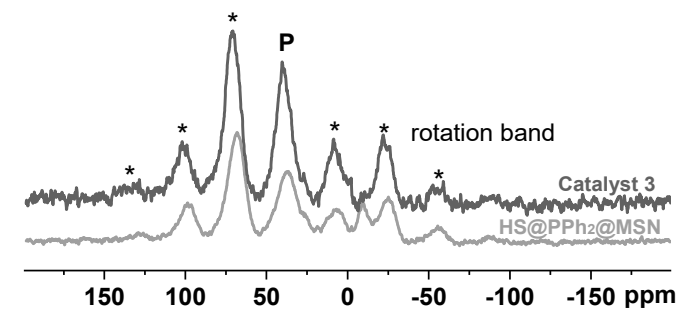

Figure 2. The solid-state ${ }^{29} \mathrm{Si}$ MAS NMR spectrum of catalyst 3. 
Additionally, the solid-state ${ }^{29}$ Si MAS NMR spectroscopy was collected and confirmed the organosilicate network and composition of catalyst 3. As shown in Figure 3, there were a few differences among the precursors ( 1 and 2 ) and catalyst 3 in the solid-state ${ }^{29} \mathrm{Si}$ MAS NMR spectra, and two typical signals (where $Q$ signals were attributed to inorganosilica, while $\mathrm{T}$ signals corresponded to organosilica) were distributed broadly from -40 to $-150 \mathrm{ppm}$. As compared to those typical isomer shift values in the literature [9], the $\mathrm{T}^{2}$ signal of the T-series at $57.1 \mathrm{ppm}$ presented the $\left\{\left(\mathrm{R}-\mathrm{Si}(\mathrm{OSi})_{2}(\mathrm{OH})\right)\right\}$ or $\left\{\left(\mathrm{R}-\mathrm{Si}(\mathrm{OSi})_{2}\left(\mathrm{CH}_{2} \mathrm{CH}_{3}\right)\right)\right\}$, where $\mathrm{R}=$ alkyl-linked $\mathrm{PPh}_{2} \mathrm{Pd}(\mathrm{OAc})_{2}$ in three and/or ethylene-bridged group in one and two, and the strongest $\mathrm{T}^{3}$ signal of the $\mathrm{T}$-series at $-67.6 \mathrm{ppm}$ suggested $\mathrm{R}-\mathrm{Si}(\mathrm{OSi})_{3}$ organosilicate species. In the silica wall of the hollow-shell silica, the intensity of $\mathrm{T}$ signals was markedly higher than that of $Q$ signals, and the other three $Q$ signals at -91 , -102 , and $-111 \mathrm{ppm}$ were attributed to $\mathrm{Q}^{2}\left(\left(\mathrm{Me}_{3} \mathrm{Si}-\mathrm{O}\right)_{4} \mathrm{Si}\right), \mathrm{Q}^{3}\left(\mathrm{Si}(\mathrm{OSi})_{3}(\mathrm{OH})\right)$, and $\mathrm{Q}^{4}$ $\left(\mathrm{Si}(\mathrm{OSi})_{4}\right)$ species coming from the TEOS precursor. The above results demonstrated that the incorporated precursors were covalently converted within its organosilica network.

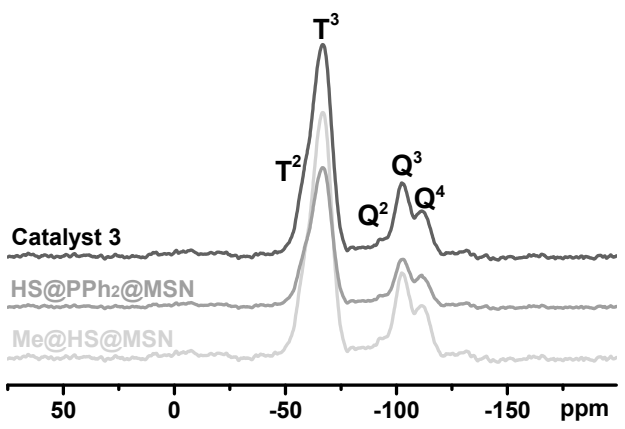

Figure 3. The solid-state ${ }^{29}$ Si MAS NMR spectrum of catalyst 3.

The morphology and ordered mesostructure of three were further investigated by scanning electron microscopy (SEM), transmission electron microscopy (TEM), and nitrogen adsorption-desorption measurements. As shown in Figure 4, the nitrogen adsorptiondesorption isotherm of three showed a typical type IV isotherm with an $\mathrm{H}_{1}$ hysteresis loop and a visible step at $P / P_{0}=0.45-0.95$ demonstrating its mesoporous structure. The pore size distribution of catalyst 3 revealed that it had uniform mesopores of about $6.3 \mathrm{~nm}$ (see Supplementary Information in Figure S3), which were similar to that of the corresponding pure Me@HS@MSN and HS@PPh $@$ MSN materials, except for the reduced surface area $\left(64.72 \mathrm{~m}^{2} / \mathrm{g}\right.$ for $\mathrm{HS} @ \mathrm{PPh}_{2} @ \mathrm{MSN}, 51.23 \mathrm{~m}^{2} / \mathrm{g}$ for catalyst 3 , versus $74.72 \mathrm{~m}^{2} / \mathrm{g}$ for Me@HS@MSN), and pore volume $\left(0.14 \mathrm{~cm}^{3} / \mathrm{g}\right.$ for HS@PPh $\mathrm{HMMN}_{2} 0.08 \mathrm{~cm}^{3} / \mathrm{g}$ for catalyst 3 , versus $0.17 \mathrm{~cm}^{3} / \mathrm{g}$ for Me@HS@MSN) suggesting that the decoration of the $\mathrm{PPh}_{2}$ and the complexation of $\mathrm{Pd}$ with $\mathrm{PPh}_{2}$ led to nanopore narrowing in catalyst 3 . Figure 5 presented the hollow-shell-structured morphology of catalyst 3 . Its SEM images showed that the nanospheres were uniformly dispersed; its average particle size was $\sim 445 \mathrm{~nm}$ (Figure $5 \mathrm{a}$ ). The TEM images were also collected and showed that each nanosphere had a cavity of $\sim 369 \mathrm{~nm}$ diameter, and the thickness of the silica shell was about $82 \mathrm{~nm}$ (Figure 5b). Further, in the TEM images, under a large-scale bar, we could find that Pd was concentrated on the inner sphere; however, the particle size of Pd was still ambiguous. This might be due to $\mathrm{Pd}^{2+}$ ions being coordinated with diphenyl(2-(triethoxysilyl)ethyl)phosphane. This phenomenon further confirmed that there were no Pd nanoparticles dispersed in the hollow cavity. Furthermore, a TEM image with chemical mapping was (Figure 5c) also collected, demonstrating that palladium active centers were successfully entrapped within the inner cavity. 


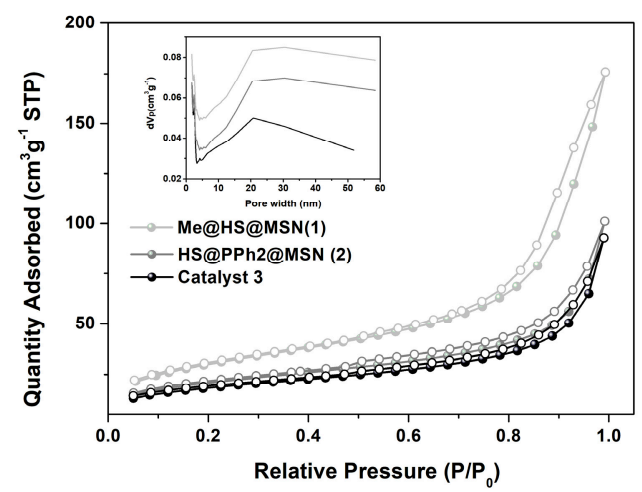

Figure 4. The nitrogen adsorption-desorption isotherms of one and catalyst 3.

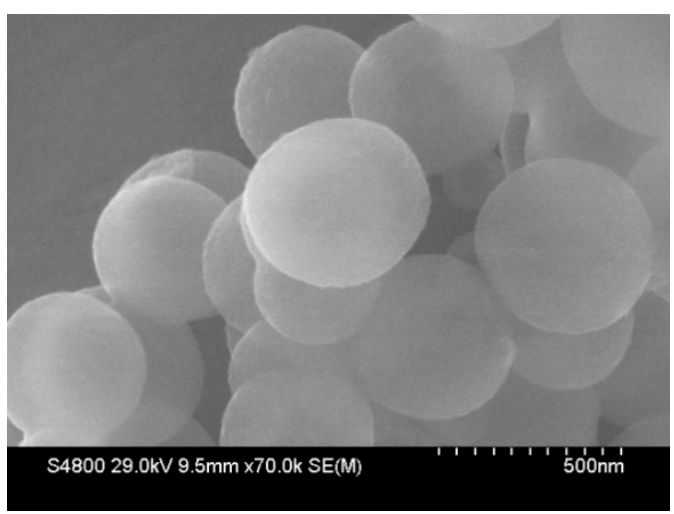

(a)

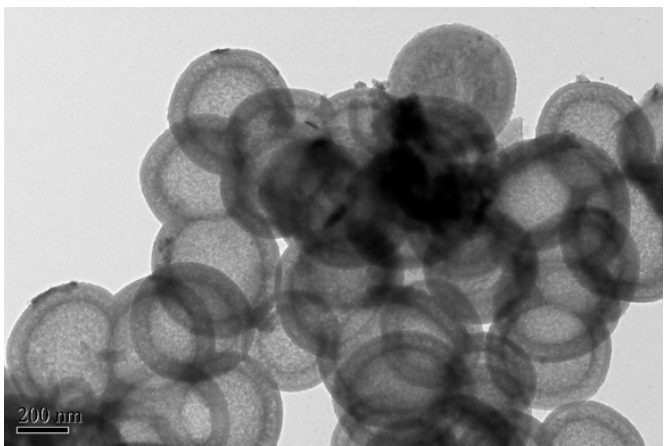

(b)

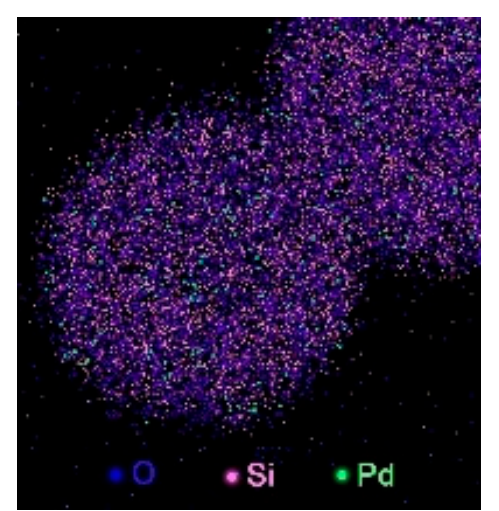

(c)

Figure 5. (a) The scanning electron microscopy (SEM) images of catalyst 3 , (b) the transmission electron microscopy (TEM) images of catalyst 3, (c) a TEM image with the chemical mapping of 3 showing the distribution of $\mathrm{Si}$ (pink), $\mathrm{O}$ (blue), and Pd (green). 


\subsection{Catalytic Performance of the Heterogeneous Catalyst}

With the obtained well-established heterogeneous catalyst on hand, a series of SuzukiMiyaura cross-coupling reactions were optimized, as shown in Table 1. During this process, we chose the Suzuki-Miyaura cross-coupling reaction of 1-iodo-4-methoxybenzene (4a) and phenylboronic acid (5a) as a model reaction, wherein the reaction was carried out by using $1.0 \mathrm{~mol} \%$ of Pd-loading in three as a catalyst at $35^{\circ} \mathrm{C}$ for the optimization of the reaction conditions. In the case of the screen of bases, we found that the $\mathrm{Na}_{2} \mathrm{CO}_{3}$ was the optimal base because the reaction produced the targeted product 4-methoxy-1,1'-biphenyl (6a) in a 95\% isolated yield, which was better than those with other bases (Table 1, entry 1 versus entries 2-6). Additionally, a series of co-solvents were screened, and the results showed that the activity of the catalyst $\mathbf{3}$ for the Suzuki-Miyaura reaction was better in the hydrophilic solvent (Table 1, entries 7-9) than in the hydrophobic solvent (Table 1, entries 10-12), and the optimal co-solvent was $\mathrm{MeOH} / \mathrm{H}_{2} \mathrm{O}(v / v=2 / 1)$. Especially, differing from the traditional high temperature for Suzuki-coupling, the catalysis activity of the catalyst 3 did not increase with increasing temperature (Table 1, entries 13-16). Those findings demonstrated that the Suzuki-Miyaura cross-coupling reaction catalyzed by catalyst 3 with $1 \mathrm{~mol} \%$ Pd-loading in $3.0 \mathrm{~mL}$ of the co-solvent $\mathrm{MeOH} / \mathrm{H}_{2} \mathrm{O}(v / v=2 / 1)$ at $35^{\circ} \mathrm{C}$ gave the best result. It was worth mentioning that the model reaction catalyzed by three had an obviously higher yield than that obtained with the homogenous $\mathrm{Pd}(\mathrm{OAc})_{2}$, and even than that with a mixture of $\mathrm{Pd}(\mathrm{OAc})_{2}$ and $\mathrm{PPh}_{3}$ (Table 1, entry 1 versus entries 2-5).

Table 1. Optimization of reaction conditions ${ }^{\text {a }}$.
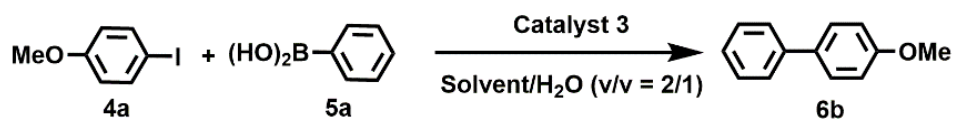

\begin{tabular}{|c|c|c|c|c|c|}
\hline Entry. & Solvent & Base & Time (h) & Temperature $\left({ }^{\circ} \mathrm{C}\right)$ & Yield (\%) ${ }^{b}$ \\
\hline 1 & $\mathrm{MeOH} / \mathrm{H}_{2} \mathrm{O}$ & $\mathrm{K}_{2} \mathrm{CO}_{3}$ & 1 & 35 & 95 \\
\hline 2 & $\mathrm{MeOH} / \mathrm{H}_{2} \mathrm{O}$ & $\mathrm{NaHCO}_{3}$ & 1 & 35 & 50 \\
\hline 3 & $\mathrm{MeOH} / \mathrm{H}_{2} \mathrm{O}$ & $\mathrm{Et}_{3} \mathrm{~N}$ & 1 & 35 & 40 \\
\hline 4 & $\mathrm{MeOH} / \mathrm{H}_{2} \mathrm{O}$ & $\mathrm{NaOH}$ & 1 & 35 & - \\
\hline 5 & $\mathrm{MeOH} / \mathrm{H}_{2} \mathrm{O}$ & DABCO & 1 & 35 & - \\
\hline 6 & $\mathrm{MeOH} / \mathrm{H}_{2} \mathrm{O}$ & DBU & 1 & 35 & - \\
\hline 7 & $\mathrm{EtOH} / \mathrm{H}_{2} \mathrm{O}$ & $\mathrm{K}_{2} \mathrm{CO}_{3}$ & 1 & 35 & 90 \\
\hline 8 & ${ }^{i} \mathrm{PrOH} / \mathrm{H}_{2} \mathrm{O}$ & $\mathrm{K}_{2} \mathrm{CO}_{3}$ & 1.5 & 35 & 90 \\
\hline 9 & Acetone $/ \mathrm{H}_{2} \mathrm{O}$ & $\mathrm{K}_{2} \mathrm{CO}_{3}$ & 1.5 & 35 & 90 \\
\hline 10 & $\mathrm{DCM} / \mathrm{H}_{2} \mathrm{O}$ & $\mathrm{K}_{2} \mathrm{CO}_{3}$ & 2 & 35 & 10 \\
\hline 11 & $\mathrm{EA} / \mathrm{H}_{2} \mathrm{O}$ & $\mathrm{K}_{2} \mathrm{CO}_{3}$ & 2 & 35 & 36 \\
\hline 12 & 1,4-dioxane & $\mathrm{K}_{2} \mathrm{CO}_{3}$ & 2 & 35 & 79 \\
\hline 13 & $\mathrm{MeOH} / \mathrm{H}_{2} \mathrm{O}$ & $\mathrm{K}_{2} \mathrm{CO}_{3}$ & 1 & 25 & 60 \\
\hline 14 & $\mathrm{MeOH} / \mathrm{H}_{2} \mathrm{O}$ & $\mathrm{K}_{2} \mathrm{CO}_{3}$ & 1 & 45 & 95 \\
\hline 15 & $\mathrm{MeOH} / \mathrm{H}_{2} \mathrm{O}$ & $\mathrm{K}_{2} \mathrm{CO}_{3}$ & 1 & 55 & 95 \\
\hline 16 & $\mathrm{MeOH} / \mathrm{H}_{2} \mathrm{O}$ & $\mathrm{K}_{2} \mathrm{CO}_{3}$ & 1 & 65 & 96 \\
\hline $17^{\mathrm{c}}$ & $\mathrm{MeOH} / \mathrm{H}_{2} \mathrm{O}$ & $\mathrm{Pd}(\mathrm{OAc})_{2}$ & 1 & 35 & 90 \\
\hline $18^{\mathrm{d}}$ & $\mathrm{MeOH} / \mathrm{H}_{2} \mathrm{O}$ & $\begin{array}{c}\mathrm{Pd}(\mathrm{OAc})_{2}+ \\
\mathrm{PPh}_{3}\end{array}$ & 1 & 35 & 50 \\
\hline $19^{\mathrm{e}}$ & $\mathrm{MeOH} / \mathrm{H}_{2} \mathrm{O}$ & $3^{\prime}$ & 1 & 35 & 90 \\
\hline
\end{tabular}

a Reaction conditions: catalyst $3(5.0 \mathrm{mg}, 1 \mathrm{~mol} \%, 5.0 \mu \mathrm{mol}$ of Pd based on the inductively coupled plasma (ICP) analysis), aryl boronic acid $(0.75 \mathrm{mmol})$, aryl halide $(0.5 \mathrm{mmol})$, and $\mathrm{K}_{2} \mathrm{CO}_{3}(1.0 \mathrm{mmol})$ in $3.0 \mathrm{~mL}$ of the co-solvent $\mathrm{MeOH} / \mathrm{H}_{2} \mathrm{O}(v / v=2 / 1)$, at $35{ }^{\circ} \mathrm{C}, 1-3 \mathrm{~h}$. ${ }^{\mathrm{b}}$ Isolated yields. ${ }^{\mathrm{c}}$ Data were obtained using $\mathrm{Pd}(\mathrm{OAc})_{2}$ as a catalyst. ${ }^{\mathrm{d}}$ Data were obtained using the mixed $\mathrm{Pd}(\mathrm{OAc})_{2}$ and $\mathrm{PPh}_{3}$ as a catalyst. ${ }^{\mathrm{e}}$ Data were obtained using the analog $3^{\prime}$ of catalyst 3 without the protection of $-\mathrm{Si}(\mathrm{Me})_{3}$ as a catalyst.

To elucidate the benefit of the surface protection of $-\mathrm{Si}(\mathrm{Me})_{3}$ for the designed silicasupported heterogeneous catalyst 3, the kinetic reaction profiling for the Suzuki-Miyaura cross-coupling reaction catalyzed by $\mathrm{Pd}(\mathrm{OAc})_{2}$, three, and $\mathbf{3}^{\prime}$ (the three capped with$\mathrm{Si}\left(\mathrm{CH}_{3}\right)_{3}$ groups was obtained by silanization of $\mathbf{3}^{\prime}$ and hexamethyldisilazane) were compared to demonstrate their differences in the catalytic performance (Figure 6). It was 
found that three had a higher reaction speed and yield than that attained with the others, elucidating that surface silanols in catalyst 3 could promote synergistically cross-coupling by concentrating reactants inside the hollow shell. This observation was strongly similar to that reported in the literature [52,53], disclosing the superiority of the designed catalyst 3.

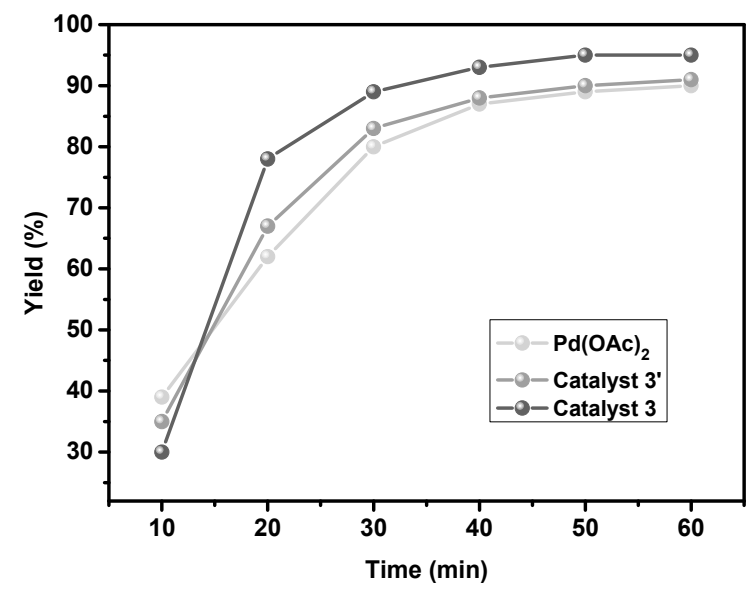

Figure 6. Kinetic results of the Suzuki-Miyaura cross-coupling reaction of 1-iodo-4-methoxybenzene and phenylboronic acid.

Having established the above catalytic system, the general applicability of the SuzukiMiyaura cross-coupling reaction was further investigated with a series of substituted aryl boronic acid and aryl halide as substrates (Table 2). As expected, catalyst 3 could convert various two-component substrates smoothly into the responding biphenyl derivatives in good yields (85-95\%), bearing both electron-donating and electron-withdrawing substituents on the meta/para-position except the aryl halide derivatives with nitro on the ortho-position, which got a relatively low yield ( $85 \%$; Table 2, entry 4$)$, similar to those reported in the literature [38].

Beyond the aim of the construction of a site-isolated heterogeneous catalyst 3 for the Suzuki-Miyaura cross-coupling reaction, another important consideration in the design of heterogeneous catalyst was the ease of separation by simple centrifugation and the ability to retain its catalytic activity and enantioselectivity after multiple recycles. It was found that the heterogeneous catalyst 3 could be easily recovered by simple centrifugation. It was found that, in five consecutive reactions, the recycled catalyst 3 could still give $90 \% e e$ in the Suzuki-Miyaura cross-coupling reaction of 1-iodo-4-methoxybenzene and phenylboronic acid (see Supplementary Information Figure S10).

Table 2. The scope of the 3-catalyzed Suzuki-Miyaura cross-coupling reaction ${ }^{\text {a }}$.

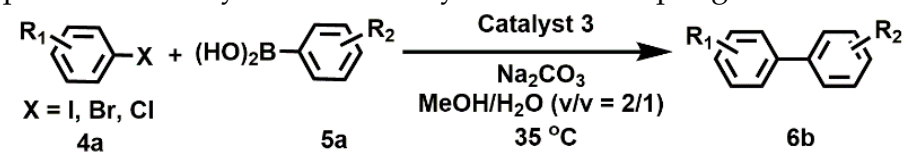

\begin{tabular}{cccccc}
\hline Entry & $\mathbf{X}$ & $\mathbf{R}_{\mathbf{1}}$ & $\mathbf{R}_{\mathbf{2}}$ & Time (h) & Yield (\%) ${ }^{\boldsymbol{b}}$ \\
\hline 1 & $\mathrm{I}$ & $4-\mathrm{COMe}$ & $\mathrm{H}$ & 1 & 95 \\
2 & $\mathrm{I}$ & $4-\mathrm{Cl}$ & $\mathrm{H}$ & 1 & 90 \\
3 & $\mathrm{I}$ & $4-\mathrm{Me}$ & $\mathrm{H}$ & 1 & 90 \\
4 & $\mathrm{Br}$ & $4-\mathrm{NO}_{2}$ & $\mathrm{H}$ & 1 & 85 \\
5 & $\mathrm{Br}$ & $4-\mathrm{Cl}$ & $\mathrm{H}$ & 1 & 95 \\
6 & $\mathrm{Br}$ & $4-\mathrm{OMe}$ & $\mathrm{H}$ & 1 & 90 \\
7 & $\mathrm{Br}$ & $2-\mathrm{Me}$ & $\mathrm{H}$ & 1 & 90 \\
8 & $\mathrm{Br}$ & $4-\mathrm{CN}$ & $\mathrm{H}$ & 1 & 92 \\
9 & $\mathrm{Br}$ & $4-\mathrm{CH}_{3}$ & $\mathrm{H}$ & 1 & 92 \\
\hline
\end{tabular}


Table 2. Cont.

\begin{tabular}{cccccc}
\hline Entry & $\mathbf{X}$ & $\mathbf{R}_{\mathbf{1}}$ & $\mathbf{R}_{\mathbf{2}}$ & Time (h) & Yield (\%) $^{\boldsymbol{b}}$ \\
\hline 10 & $\mathrm{Br}$ & $4-\mathrm{Cl}$ & $4-\mathrm{CF}_{3}$ & 1 & 95 \\
11 & $\mathrm{Br}$ & $4-\mathrm{CN}$ & $4-\mathrm{CF}_{3}$ & 4 & 85 \\
12 & $\mathrm{Br}$ & $4-\mathrm{Me}$ & $4-\mathrm{CF}_{3}$ & 1 & 93 \\
13 & $\mathrm{Br}$ & $4-\mathrm{OMe}$ & $4-\mathrm{OMe}$ & 1.5 & 90 \\
14 & $\mathrm{Br}$ & $4-\mathrm{CN}$ & $4-\mathrm{OMe}$ & 1 & 95 \\
15 & $\mathrm{Br}$ & $4-\mathrm{Me}$ & $4-\mathrm{OMe}$ & 1.5 & 94 \\
16 & $\mathrm{Br}$ & $4-\mathrm{Cl}$ & $4-\mathrm{OMe}$ & 1 & 92 \\
17 & $\mathrm{Br}$ & $4-\mathrm{OH}$ & $\mathrm{H}$ & 1 & 95 \\
18 & $\mathrm{Br}$ & $\mathrm{H}$ & $4-\mathrm{OMe}$ & 1 & 95 \\
19 & $\mathrm{Br}$ & $\mathrm{H}$ & $4-\mathrm{CF}_{3}$ & 1 & 95 \\
20 & $\mathrm{Br}$ & $\mathrm{COMe}$ & $\mathrm{H}$ & 1 & 95 \\
21 & $\mathrm{Br}$ & $\mathrm{COMe}$ & $4-\mathrm{OMe}$ & 1 & 95 \\
\hline
\end{tabular}

a Reaction conditions: catalyst $3(5.0 \mathrm{mg}, 1 \mathrm{~mol} \%, 5.0 \mu \mathrm{mol}$ of Pd based on the ICP analysis), aryl boronic acid $(0.75 \mathrm{mmol})$, aryl halide $(0.5 \mathrm{mmol})$, and $\mathrm{K}_{2} \mathrm{CO}_{3}(1.0 \mathrm{mmol})$ in $3.0 \mathrm{~mL}$ of the co-solvent $\mathrm{MeOH} / \mathrm{H}_{2} \mathrm{O}(v / v=2 / 1)$, at $35^{\circ} \mathrm{C}, 1-3 \mathrm{~h}^{b}{ }^{b}$ Isolated Yield.

\section{Experimental}

\subsection{Characterization}

The Fourier transform infrared (FTIR) spectra were collected by using the KBr method on a Nicolet Magna 550 spectrometer. Nitrogen adsorption isotherms were measured at $77 \mathrm{~K}$ with a Quantachrome Nova 4000 analyzer. The samples were measured after being outgassed at $423 \mathrm{~K}$ overnight. Pore size distributions were calculated by using the BJH model. The specific surface areas (SBET) of samples were determined from the linear parts of the BET plots $\left(P / P_{0}=0.05-0.3\right)$. Solid-state NMR experiments were explored on a Bruker AVANCE spectrometer at a magnetic field strength of $9.4 \mathrm{~T}$ with an ${ }^{1} \mathrm{H}$ frequency of $400.1 \mathrm{MHz}$, a ${ }^{13} \mathrm{C}$ frequency of $100.5 \mathrm{MHz}$, and a ${ }^{29} \mathrm{Si}$ frequency of $79.4 \mathrm{MHz}$ with $4 \mathrm{~mm}$ rotor at two spinning frequencies of $5.5 \mathrm{kHz}$ and $8.0 \mathrm{kHz}$; TPPM decoupling was applied during the acquisition period. ${ }^{1} \mathrm{H}$ cross-polarization in all-solid-state NMR experiments was employed using a contact time of $2 \mathrm{~ms}$ and the pulse lengths of $4 \mu \mathrm{s}$. Scanning electron microscopy (SEM) images were obtained using a JEOL JSM-6380LV microscope operating at $29 \mathrm{kV}$. Transmission electron microscopy (TEM) images were performed on a JEOL JEM2010 electron microscope at an acceleration voltage of $220 \mathrm{kV}$.

\subsection{Preparation of the Catalyst 3}

The silicate yolk was synthesized according to the method descibed in the literature. First, dissolving the cetyltrimethylammonium bromide (CTAB, $0.10 \mathrm{~g}, 0.27 \mathrm{mmol}$ ) completely in an aqueous sodium hydroxide $(45.0 \mathrm{~mL}, 0.35 \mathrm{mmol}, 2.0 \mathrm{~N})$, and stirring the mixture for $0.5 \mathrm{~h}$ at $80^{\circ} \mathrm{C}$. Subsequently, tetraethoxysilane (TEOS, $0.46 \mathrm{~mL}, 2.07 \mathrm{mmol}$ ) was dropped under vigorous stirring at room temperature. Finally, ethyl acetate $(0.40 \mathrm{~mL})$ was added, and the mixture was stirred for $2 \mathrm{~h}$ at $80^{\circ} \mathrm{C}$. The second step was to coat the above silicate yolk. After cooling down the above reaction mixture to $38^{\circ} \mathrm{C}$, an aqueous solution containing water $(80 \mathrm{~mL})$, ethanol $(50 \mathrm{~mL}), \mathrm{CTAB}(0.30 \mathrm{~g}, 0.82 \mathrm{mmol})$, and $\mathrm{NH}_{3} \cdot \mathrm{H}_{2} \mathrm{O}$ $(25 \mathrm{wt} \%, 1.0 \mathrm{~mL})$ was added. The mixture was stirred again at $38^{\circ} \mathrm{C}$ for $0.5 \mathrm{~h}$, an additional part of the TEOS $(0.5 \mathrm{~mL}, 2.26 \mathrm{mmol})$ was added, and the mixture was stirred for another $2 \mathrm{~h}$ at $38^{\circ} \mathrm{C}$. Then, $3 \mathrm{~mL}$ of a mixture solution containing $\mathrm{H}_{2} \mathrm{O}(3.0 \mathrm{~mL}), \mathrm{CTAB}(0.080 \mathrm{~g}$, $0.22 \mathrm{mmol})$, and $\mathrm{NH}_{3} \cdot \mathrm{H}_{2} \mathrm{O}(25 \mathrm{wt} \%, 0.20 \mathrm{~mL})$ was added and stirred at $38^{\circ} \mathrm{C}$ for $0.5 \mathrm{~h}$. Finally, 1,2-bis(triethoxysilyl)ethane $(0.89 \mathrm{~g}, 0.70 \mathrm{mmol})$ were added and the reactant was vigorously stirred for $2.0 \mathrm{~h}$. After filtering and washing with $\mathrm{H}_{2} \mathrm{O}$ and EtOH three times and dried at $60{ }^{\circ} \mathrm{C}$ in a vacuum drying oven, the $\mathrm{SiO}_{2} @ \mathrm{NPs}$ (about $1 \mathrm{~g}$ ) were obtained. $\mathrm{SiO}_{2} @$ NPs $(1 \mathrm{~g})$ were added into a $100 \mathrm{~mL}$ schlenk tube in an argon atmosphere; then, $25 \mathrm{~mL}$ anhydrous toluene containing hexamethyldisiloxane (HMDS, $5.0 \mathrm{~mL}, 0.025 \mathrm{mmol}$ ) was dropped into the schlenk tube, and stirred at room temperature for $24 \mathrm{~h}$. The solid (Me@SiO $\left.{ }_{2} @ N P s\right)$ was obtained after filtration and washed with acetone. The third step 
was the selective etching to remove the surfactant and form the yolk-shell-structured mesoporous nanoparticles. Immersing the collected solids $(1.0 \mathrm{~g})$ in an ammonium nitrate $(80 \mathrm{mg}, 1.0 \mathrm{mmol})$ solution of ethanol $(120 \mathrm{~mL}, 95 \%)$ and stirring the mixture at $60^{\circ} \mathrm{C}$ for $12 \mathrm{~h}$ left the target hollow-shell structures of Me@HS@MSN (1) as a white powder (0.65 g) after filtering and washing it with excess water and ethanol, and drying it at ambient temperature in a vacuum overnight. (IR $(\mathrm{KBr}) \mathrm{cm}^{-1}: 3433.1(\mathrm{w}), 2924.4(\mathrm{~m}), 2853.9(\mathrm{~s}), 2360.65$ $(\mathrm{m}), 2340.9(\mathrm{~m}), 1636.7(\mathrm{~s}), 1372.43(\mathrm{~s}), 1164.3(\mathrm{~s}), 1055.2(\mathrm{w}), 785.6(\mathrm{~s}), 457.3(\mathrm{~m}) .{ }^{13} \mathrm{C} \mathrm{CP}$ MAS NMR (161.9 MHz): 67.9-59.9 $\left(\mathrm{CH}_{2}\right.$ of $\left.-\mathrm{OCH}_{2} \mathrm{CH}_{3}\right), 29.7-25.7\left(\mathrm{C}\right.$ of $\left.-\mathrm{SCH}_{2},\right), 4.9(\mathrm{C}$ of $-\mathrm{Si}\left(\mathrm{CH}_{3}\right)_{3}$ group) ppm. ${ }^{29} \mathrm{Si} \mathrm{MAS} \mathrm{NMR}(79.4 \mathrm{MHz}): \mathrm{T}^{2}(\delta=-57.3 \mathrm{ppm}), \mathrm{T}^{3}(\delta=-66.1 \mathrm{ppm})$, $\left.\mathrm{Q}^{2}(\delta=-91.0 \mathrm{ppm}), \mathrm{Q}^{3}(\delta=-102.4 \mathrm{ppm}), \mathrm{Q}^{4}(\delta=-112.2 \mathrm{ppm})\right)$. The fourth step was the thiol-ene click reaction. A dried $50 \mathrm{~mL}$ schlenk tube was charged with Me@HS@MSN (1) $(0.725 \mathrm{~g}), 2$-(diphenylphosphino)ethyltriethoxysilane $(0.25 \mathrm{~mL})$, and anhydrous toluene $(20 \mathrm{~mL})$ in an argon atmosphere. The mixture was stirred at $137^{\circ} \mathrm{C}$ for $24 \mathrm{~h}$, then filtered and rinsed with excess toluene. The homogeneous and unreacted starting materials were removed after Soxhlet extraction for $24 \mathrm{~h}$ in toluene, and the obtained solid $\mathrm{HS} @ \mathrm{PPh}_{2} @ \mathrm{MSN}$ (2; $0.5 \mathrm{~g}$, light-yellow powder) was dried at $60{ }^{\circ} \mathrm{C}$ in a vacuum overnight. $\mathrm{IR}(\mathrm{KBr}) \mathrm{cm}^{-1}$ : $3400.8(\mathrm{w}), 3127.3(\mathrm{w}), 2925.1(\mathrm{~s}), 2854.5(\mathrm{~s}), 1771.9(\mathrm{~s}), 1686.0(\mathrm{~s}), 1400.7(\mathrm{w}), 1269.2(\mathrm{~s})$, $1161.3(\mathrm{~s}), 1062.4(\mathrm{~s}), 789.7(\mathrm{~m}), 699.3(\mathrm{~m}), 456.2(\mathrm{~m}) .{ }^{13} \mathrm{C}$ CP MAS NMR (161.9 MHz): 191.1-177.8 ( $\mathrm{C}$ of $\mathrm{C}=\mathrm{O}$ groups), $154.8-127.2(\mathrm{C}$ of $\mathrm{Ph}), 63.5\left(\mathrm{CH}_{2}\right.$ of $\left.-\mathrm{OCH}_{2} \mathrm{CH}_{3}\right), 31.3$ $26.9\left(\mathrm{C}\right.$ of $\left.\mathrm{CH}_{2} \mathrm{P}(\mathrm{Ph})_{2}\right), 23.4-17.2\left(\mathrm{C}\right.$ of $\left.\mathrm{OCH}_{2} \mathrm{CH}_{3}\right), 6.49\left(\mathrm{C}\right.$ of $-\mathrm{SCH}_{2},-\mathrm{Si}\left(\mathrm{CH}_{3}\right)_{2} \mathrm{ppm} .{ }^{29} \mathrm{Si}$ MAS NMR (79.4 MHz): $\mathrm{T}^{2}(\delta=-56.7 \mathrm{ppm}), \mathrm{T}^{3}(\delta=-66.5 \mathrm{ppm}), \mathrm{Q}^{2}(\delta=-92.7 \mathrm{ppm}), \mathrm{Q}^{3}$ $(\delta=-102.5 \mathrm{ppm}), \mathrm{Q}^{4}(\delta=-111.7 \mathrm{ppm}) .{ }^{31} \mathrm{P}$ CP $/$ MAS NMR: $37.3 \mathrm{ppm}$. The fifth step was to immobilize the $\mathrm{Pd}^{2+}$ on the inner sphere by thiol-ene click reaction. A dried $50 \mathrm{~mL}$ schlenk tube was charged with $\mathrm{HS}_{\mathrm{PPh}} @ \mathrm{MSN}(2 ; 0.50 \mathrm{~g}), \mathrm{Pd}(\mathrm{OAc})_{2}(50 \mathrm{mg})$, and anhydrous DCM (dichloromethane) $(20 \mathrm{~mL})$ in an argon atmosphere. The mixture was stirred at room temperature for $12 \mathrm{~h}$; then filtered and washed with excess EtOH three times. The unreacted $\mathrm{Pd}(\mathrm{OAc})_{2}$ was removed by Soxhlet extraction for $24 \mathrm{~h}$ in $\mathrm{DCM}$, and then the solid was dried at $60{ }^{\circ} \mathrm{C}$ in a vacuum to retrieve the target $\mathrm{HS} @ \mathrm{PdPPh}_{2} @ \mathrm{MSN}(3 ; 0.5 \mathrm{~g})$ as a light-yellow powder. The inductively coupled plasma (ICP) analysis showed that the Pd loading amount was $110.6 \mathrm{mg}(1.03 \mathrm{mmol})$ per gram catalyst. IR $(\mathrm{KBr}) \mathrm{cm}^{-1}: 3403.2$ (s), $3166.5(\mathrm{~m}), 3144.6(\mathrm{w}), 2925.3(\mathrm{w}), 2855.2(\mathrm{~s}), 2360.3(\mathrm{~m}), 2340.2(\mathrm{~m}), 1649.7(\mathrm{~m}), 188.4$ $(\mathrm{s}), 1400.8(\mathrm{~m}), 1269.6(\mathrm{~s}), 1160.6(\mathrm{w}), 1066.6(\mathrm{~s}), 786.7(\mathrm{~m}), 694.3(\mathrm{~m}), 456.1(\mathrm{~m}) .{ }^{13} \mathrm{C} \mathrm{CP}$ MAS NMR (161.9 MHz): 188.5-174.3 ( $\underline{C}$ of $\mathrm{C}=\mathrm{O}$ groups), $152.0-121.0(\mathrm{C}$ of $\mathrm{Ph}), 63.4\left(\mathrm{CH}_{2}\right.$ of $\left.-\mathrm{OCH}_{2} \mathrm{CH}_{3}\right), 26.9\left(\mathrm{C}\right.$ of $\left.\mathrm{CH}_{2} \mathrm{P}(\mathrm{Ph})_{2}\right), 18.9\left(\mathrm{C}\right.$ of $\mathrm{CH}_{3} \mathrm{CO}$ and $\left.\mathrm{OCH}_{2} \mathrm{CH}_{3}\right), 5.6\left(\mathrm{C}\right.$ of $-\mathrm{SCH}_{2}$, $-\mathrm{Si}\left(\mathrm{CH}_{3}\right)_{2} \mathrm{ppm} .{ }^{29} \mathrm{Si} \mathrm{MAS}$ NMR $(79.4 \mathrm{MHz}): \mathrm{T}^{2}(\delta=-57.1 \mathrm{ppm}), \mathrm{T}^{3}(\delta=-67.63 \mathrm{ppm})$, $\mathrm{Q}^{2}(\delta=-91.0 \mathrm{ppm}), \mathrm{Q}^{3}(\delta=-103.0 \mathrm{ppm}), \mathrm{Q}^{4}(\delta=-112.3 \mathrm{ppm}) .{ }^{31} \mathrm{P} \mathrm{CP} / \mathrm{MAS}$ NMR (169.3 MHz): 39.9 ppm.

\subsection{General Procedure for the Suzuki-Miyaura Cross-Coupling}

Catalyst $3(5.0 \mu \mathrm{mol}$ of Pd based on the ICP analysis, $5.0 \mathrm{mg}, 1 \mathrm{~mol} \%)$, aryl boronic acid $(0.75 \mathrm{mmol})$, aryl halide $(0.5 \mathrm{mmol}), \mathrm{K}_{2} \mathrm{CO}_{3}(1.0 \mathrm{mmol})$, and $3.0 \mathrm{~mL} \mathrm{MeOH} / \mathrm{H}_{2} \mathrm{O}$ $(v / v=2 / 1)$ co-solvent were added into a $10 \mathrm{~mL}$ round-bottom flask; then the mixture was allowed to react for $1-3 \mathrm{~h}$ at $35^{\circ} \mathrm{C}$. The reaction was monitored by TLC (thin layer chromatography) to determine the completion of the reaction. Then the catalyst was separated by centrifugation $(10,000 \mathrm{rpm})$ for the recycling experiment, while the aqueous solution was extracted by $\mathrm{Et}_{2} \mathrm{O}(3 \times 3.0 \mathrm{~mL})$. Further, the combined organic phase was washed by brine and dehydrated with $\mathrm{Na}_{2} \mathrm{SO}_{4}$. After the concentration, the desired product was purified by column chromatography.

\section{Conclusions}

In conclusion, a palladium diphenylphosphine-based hollow-shell-structured mesoporous silica heterogeneous catalyst 3 was prepared. The structure of catalyst 3 was ana-

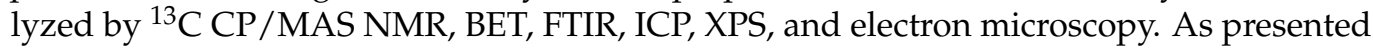
in this study, catalyst 3 realized an efficient Suzuki-Miyaura cross-coupling of 1-iodo-4- 
methoxybenzene and phenylboronic acid to afford a range of biaryls with up to $95 \%$ yield; the activity was comparable to those of related homogeneous and other core/hollow shell solid catalysts. Additionally, catalyst 3 could be recovered after filtering and washing and maintained its high activity in four consecutive reactions in Suzuki-Miyaura coupling. This work offered a perspective approach to design heterogeneous catalysts for high catalytic activity and cost-effective catalysis.

Supplementary Materials: The following are available online at https: / www.mdpi.com/article / 10.3390/catal11050582/s1, Figure S1: FT-IR spectra of Catalyst 1, PMOs, ArDPEN@PMOs and Catalyst 2; Figure S2: Solid-state ${ }^{13} \mathrm{C} \mathrm{CP} / \mathrm{MAS}$ NMR spectra of Catalyst $3^{\prime}$, Figure S3: Solid-state ${ }^{13} \mathrm{C}$ CP/MAS NMR spectra of Me@HS@MSN, HS@PPh2@MSN and Catalyst 3, Figure S4: Solid-state 29Si MAS NMR spectra of Me@HS@MSN, HS@PPh2@MSN and Catalyst 3, Figure S5: Solid-state 31P CP/MAS NMR spectra of Me@HS@MSN, HS@PPh2@MSN and Catalyst 3, Figure S6: SEM image of Catalyst 3, Figure S7: TEM images and the corresponding EDS mapping of Catalyst 3, Figure S8: XPS spectra of the Catalyst 3, Figure S9: TGA of the Me@HS@MSN (1),HS@PPh2@MSN (2) and Catalyst 3, Figure S10: Reusability of Catalyst 3 in the Suzuki- Miyaura cross-coupling reaction of 1-iodo-4-methoxybenzene and phenylboronic acid, Figure S11: 1H NMR spectra.

Author Contributions: A.T.A.M. prepared the heterogeneous catalyst and finished the corresponding characterization and catalysis. L.W. is responsible for the NMR analysis, R.J. and G.L. are responsible for the characterization analysis, and C.T. finished the writing. All authors have read and agreed to the published version of the manuscript.

Funding: This research was funded by [the China National Natural Science Foundation] grant number [22071154, 22001171], [the Shanghai Sciences and Technologies Development Fund] grant number [20070502600], and [the Shanghai Sailing Program] grant number [2020YF1435200].

Informed Consent Statement: Informed consent was obtained from all subjects involved in the study.

Acknowledgments: We are grateful to the China National Natural Science Foundation (22071154, 22001171), the Shanghai Sciences and Technologies Development Fund (20070502600), and the Shanghai Sailing Program (2020YF1435200) for financial support.

Conflicts of Interest: The authors declare no conflict of interest.

\section{References}

1. Chen, B.W.J.; Xu, L.; Mavrikakis, M. Computational Methods in Heterogeneous Catalysis. Chem. Rev. 2021, 121, 1007-1048. [CrossRef] [PubMed]

2. Mizuno, N.; Misono, M. Heterogeneous Catalysis. Chem. Rev. 1998, 98, 199-218. [CrossRef] [PubMed]

3. Corma, A.; Garcí, H.; Xamena, F.X.L.I. Engineering Metal-Organic Framework for Heterogeneous Catalysis. Chem. Rev. 2010, 110, 4606. [CrossRef]

4. Miyaura, N.; Suzuki, A. Palladium-Catalyzed Cross-Coupling Reactions of Organoboron Compounds. Chem. Rev. 1995, 95, 2457-2483. [CrossRef]

5. Nicolaou, K.C.; Bulger, P.G.; Sarlah, D. Palladium-Catalyzed Cross-Coupling Reactions in Total Synthesis. Angew. Chem. Int. Ed. 2005, 44, 4442-4489. [CrossRef] [PubMed]

6. Leblond, C.R.; Andrews, A.T.; Sun, Y.; Sowa, J.R. Activation of Aryl Chlorides for Suzuki Cross-Coupling by Ligandless, Heterogeneous Palladium. Org. Lett. 2001, 3, 1555-1557. [CrossRef]

7. Seechurn, C.C.C.J.; Kitching, M.O.; Colacot, T.J.; Snieckus, V. Palladium-Catalyzed Cross-Coupling: A Historical Contextual Perspective to the 2010 Nobel Prize. Angew. Chem. Int. Ed. 2012, 51, 5062-5085. [CrossRef]

8. Kotha, S.; Lahiri, K.; Kashinath, D. Recent applications of the Suzuki-Miyaura cross-coupling reaction in organic synthesis. Tetrahedron 2002, 58, 9633-9695. [CrossRef]

9. Chatterjee, A.; Ward, T.R. Recent Advances in the Palladium Catalyzed Suzuki-Miyaura Cross-Coupling Reaction in Water. Catal. Lett. 2016, 146, 820-840. [CrossRef]

10. Marin, R.; Buchwald, S.L. Palladium-Catalyzed Suzuki-Miyaura Cross Coupling Reactions Employing Dialkylbiaryl Phosphine Ligands. Acc. Chem. Res. 2008, 41, 1461. [CrossRef] [PubMed]

11. Lennox, A.J.J.; Lloyd-Jones, G.C. Selection of boron reagents for Suzuki-Miyaura coupling. Chem. Soc. Rev. 2014, 43, 412-443. [CrossRef] [PubMed]

12. Maluenda, I.; Navarro, O. Recent Developments in the Suzuki-Miyaura Reaction: 2010-2014. Molecules 2015, 20 , 7528-7557. [CrossRef] [PubMed] 
13. Shen, X.; Jones, G.O.; Watson, D.A.; Bhayana, B.; Buchwald, S.L. Enantioselective Synthesis of Axially Chiral Biaryls by the Pd-Catalyzed Suzuki-Miyaura Reaction: Substrate Scope and Quantum Mechanical Investigations. J. Am. Chem. Soc. 2010, 132, 11278-11287. [CrossRef]

14. Lebel, H.; Janes, M.K.; Charette, A.A.B.; Nolan, S.P. Structure and Reactivity of "Unusual" N-Heterocyclic Carbene (NHC) Palladium Complexes Synthesized from Imidazolium Salts. J. Am. Chem. Soc. 2004, 126, 5046-5047. [CrossRef] [PubMed]

15. Chalker, J.M.; Wood, C.S.C.; Davis, B.G. A Convenient Catalyst for Aqueous and Protein Suzuki-Miyaura Cross-Coupling. J. Am. Chem. Soc. 2009, 131, 16346-16347. [CrossRef]

16. Lima, C.F.R.A.C.; Rodrigues, A.S.M.C.; Silva, A.M.S.; Santos, L. Role of the Base and Control of Selectivity in the Suzuki-Miyaura Cross-Coupling Reaction. ChemCatChem 2014, 6. [CrossRef]

17. Zapf, A.; Ehrentraut, A.; Beller, M. A New Highly Efficient Catalyst System for the Coupling of Nonactivated and Deactivated Aryl Chlorides with Arylboronic Acid. Angew. Chem. Int. Ed. 2000, 39, 4153. [CrossRef]

18. Wünsche, M.A.; Mehlmann, P.; Witteler, T.; Buß, F.; Rathmann, P.; Dielmann, F. Imidazolin-2-ylidenaminophosphines as Highly Electron-Rich Ligands for Transition-Metal Catalysts. Angew. Chem. Int. Ed. 2015, 54, 11857-11860. [CrossRef]

19. Fujihara, T.; Yoshida, S.; Ohta, H.; Tsuji, Y. Triarylphosphanes with Dendritically Arranged Tetraethylene Glycol Moieties at the Periphery: An Efficient Ligand for the Palladium-Catalyzed Suzuki-Miyaura Coupling Reaction. Angew. Chem. Int. Ed. 2008, 47, 8310-8314. [CrossRef]

20. Botella, L.; Naájera, C. A Convenient Oxime-CarbapalladacycleCatalyzed Suzuki Cross-Coupling of Aryl Chlorides in Water. Angew. Chem. Int. Ed. 2002, 41, 179. [CrossRef]

21. Snelders, D.J.M.; van Koten, G.; Gebbink, R.J.M.K. Hexacationic Dendriphos Ligands in the Pd-Catalyzed Suzuki-Miyaura Cross-Coupling Reaction: Scope and Mechanistic Studies. J. Am. Chem. Soc. 2009, 131, 11407-11416. [CrossRef] [PubMed]

22. George, S.M. Introduction: Heterogeneous Catalysis. Chem. Rev. 1995, 95, 475-476. [CrossRef]

23. Crudden, C.M.; Sateesh, M.; Lewis, R. Mercaptopropyl-Modified Mesoporous Silica: A Remarkable Support for the Preparation of a Reusable, Heterogeneous Palladium Catalyst for Coupling Reactions. J. Am. Chem. Soc. 2005, 127, 10045-10050. [CrossRef] [PubMed]

24. Jin, M.-J.; Lee, D.-H. A Practical Heterogeneous Catalyst for the Suzuki, Sonogashira, and Stille Coupling Reactions of Unreactive Aryl Chlorides. Angew. Chem. Int. Ed. 2010, 49, 1119-1122. [CrossRef]

25. Qiu, H.; Sarkar, S.M.; Lee, D.-H.; Jin, M.-J. Highly effective silica gel-supported N-heterocyclic carbene-Pd catalyst for SuzukiMiyaura coupling reaction. Green Chem. 2008, 10, 37-40. [CrossRef]

26. Liu, Y.; Lou, B.; Shangguan, L.; Cai, J.; Zhu, H.; Shi, B. Pillar[5]arene-Based Organometallic Cross-Linked Polymer: Synthesis, Structure Characterization, and Catalytic Activity in the Suzuki-Miyaura Coupling Reaction. Macromolecules 2018, $51,1351$. [CrossRef]

27. Noh, T.H.; Hong, W.; Lee, H.; Jung, O.-S. Indistinguishability and distinguishability between amide and ester moieties in the construction and properties of M 6 L 8 octahedral nanocages. Dalton Trans. 2014, 44, 787-794. [CrossRef]

28. Iwai, T.; Harada, T.; Hara, K.; Sawamura, M. Threefold Cross-Linked Polystyrene-Triphenylphosphane Hybrids: Mono-P-Ligating Behavior and Catalytic Applications for Aryl Chloride Cross-Coupling and C(sp3)-H Borylation. Angew. Chem. Int. Ed. 2013, 52, 12322-12326. [CrossRef]

29. Zhang, C.; Wang, J.-J.; Liu, Y.; Ma, H.; Yang, X.-L.; Xu, H.-B. Main-Chain Organometallic Microporous Polymers Based on Triptycene: Synthesis and Catalytic Application in the Suzuki-Miyaura Coupling Reaction. Chem. A Eur. J. 2013, 19, 5004-5008. [CrossRef]

30. Chen, J.; Zhang, J.; Zhu, D.; Li, T. Porphyrin-based polymer-supported palladium as an excellent and recyclable catalyst for Suzuki-Miyaura coupling reaction in water. Appl. Organomet. Chem. 2018, 32, e3996. [CrossRef]

31. Yuan, B.; Pan, Y.; Li, Y.; Yin, B.; Jiang, H. A Highly Active Heterogeneous Palladium Catalyst for the Suzuki-Miyaura and Ullmann Coupling Reactions of Aryl Chlorides in Aqueous Media. Angew. Chem. Int. Ed. 2010, 49, 4054-4058. [CrossRef] [PubMed]

32. Zhu, N.; Wei, Z.; Chen, C.; Wang, D.; Cao, C.; Qiu, Q.; Jiang, J.; Wang, H.; Su, C. Self-Generation of Surface Roughness by Low-Surface-Energy Alkyl Chains for Highly Stable Superhydrophobic/Superoleophilic MOFs with Multiple Functionalities. Angew. Chem. 2019, 131, 17189-17196. [CrossRef]

33. Li, G.; Yang, H.; Lia, W.; Zhang, G. Rationally designed palladium complexes on a bulky N-heterocyclic carbene-functionalized organosilica: An efficient solid catalyst for the Suzuki-Miyaura coupling of challenging aryl chlorides. Green Chem. 2011, 13, 2939. [CrossRef]

34. Lou, X.W.; Archer, L.A.; Yang, Z. Hollow Micro-/Nanostructures: Synthesis and Applications. Adv. Mater. 2008, 20, 3987-4019. [CrossRef]

35. Lee, J.; Park, J.C.; Song, H. A Nanoreactor Framework of a $\mathrm{Au} @ \mathrm{SiO}_{2}$ Yolk/Shell Structure for Catalytic Reduction of $p$-Nitrophenol. Adv. Mater. 2008, 20, 1523. [CrossRef]

36. Van Gough, D.; Wolosiuk, A.; Braun, P.V. Mesoporous ZnS Nanorattles: Programmed Size Selected Access to Encapsulated Enzymes. Nano Lett. 2009, 9, 1994-1998. [CrossRef] [PubMed]

37. Kamata, K.; Lu, Y.; Xia, Y. Synthesis and Characterization of Monodispersed Core-Shell Spherical Colloids with Movable Cores. J. Am. Chem. Soc. 2003, 125, 2384-2385. [CrossRef]

38. Liu, J.; Qiao, S.Z.; Hartono, S.B.; Lu, G.Q. (Max) Monodisperse Yolk-Shell Nanoparticles with a Hierarchical Porous Structure for Delivery Vehicles and Nanoreactors. Angew. Chem. Int. Ed. 2010, 49, 4981-4985. [CrossRef] 
39. Teng, Z.; Su, X.; Zheng, Y.; Sun, J.; Chen, G.; Tian, C.; Wang, J.; Li, H.; Zhao, Y.; Lu, G. Mesoporous Silica Hollow Spheres with Ordered Radial Mesochannels by a Spontaneous Self-Transformation Approach. Chem. Mater. 2013, 25, 98-105. [CrossRef]

40. Liu, J.; Xia, H.; Xue, D.F.; Lu, L. Double-Shelled Nanocapsules of V2O5-Based Composites as High-Performance Anode and Cathode Materials for Li Ion Batteries. J. Am. Chem. Soc. 2009, 131, 12086. [CrossRef]

41. Lou, X.W.; Li, C.M.; Archer, L.A. Designed Synthesis of Coaxial SnO2@carbon Hollow Nanospheres for Highly Reversible Lithium Storage. Adv. Mater. 2009, 21, 2536-2539. [CrossRef]

42. Lee, K.T.; Jung, Y.S.; Oh, S.M. Synthesis of Tin-Encapsulated Spherical Hollow Carbon for Anode Material in Lithium Secondary Batteries. J. Am. Chem. Soc. 2003, 125, 5652-5653. [CrossRef]

43. Zhang, W.M.; Hu, J.S.; Guo, Y.G.; Zheng, S.F.; Zhong, L.S.; Song, W.G.; Wan, L.J. Tin-Nanoparticles Encapsulated in Elastic Hollow Carbon Speheres for High-Performance Anode Material in Lithium-Ion Batteries. Adv. Mater. 2008, 20, 1160. [CrossRef]

44. Li, H.X.; Bian, Z.F.; Zhu, J.; Huo, Y.N.; Li, H.X.; Lu, Y.F. Mesoporous Titania Spheres with Tunable Chamber Stucture and Enhanced Photocatalytic Activity. J. Am. Chem. Soc. 2007, 129, 8406. [CrossRef]

45. Chang, F.; Wang, S.; Zhao, Z.; Wang, L.; Cheng, T.; Liu, G. Enantioselective Dual-Catalysis: A Sequential Michael Addition/Asymmetric Transfer Hydrogenation of $\alpha$-Nitrosulfone and Enones. ACS Catal. 2020, 10, 10381. [CrossRef]

46. Meng, J.; Chang, F.; Su, Y.; Liu, R.; Cheng, T.; Liu, G. Switchable Catalysts Used to Control Suzuki Cross-Coupling and Aza-Michael Addition/Asymmetric Transfer Hydrogenation Cascade Reactions. ACS Catal. 2019, 9, 8693-8701. [CrossRef]

47. Woo, H.; Lee, K.; Park, K.H. Optimized Dispersion and Stability of Hybrid Fe3O4/Pd Catalysts in Water for Suzuki Coupling Reactions: Impact of Organic Capping Agents. ChemCatChem 2014, 6, 1635-1640. [CrossRef]

48. Zhang, X.; Zhao, Y.; Xu, S.; Yang, Y.; Liu, J.; Wei, Y.; Yang, Q. Polystyrene sulphonic acid resins with enhanced acid strength via macromolecular self-assembly within confined nanospace. Nat. Commun. 2014, 5, 3170. [CrossRef] [PubMed]

49. Yang, Y.; Liu, X.; Li, X.; Zhao, J.; Bai, S.; Liu, J.; Yang, Q. A Yolk-Shell Nanoreactor with a Basic Core and an Acidic Shell for Cascade Reactions. Angew. Chem. Int. Ed. 2012, 51, 9164-9168. [CrossRef]

50. Baer, H.H.; Urbas, L. The Chemistry of Nitro and Nitroso Groups; Patai, S., Ed.; Interscience: New York, NY, USA, 1970 ; p. 117.

51. Krőcher, O.; Kőppel, O.A.; Frőba, M.; Baiker, A. Silica Hybrid Gel Catalysts Containing Group(VIII) Transition Metal Complexes: Preparation, Structural, and Catalytic Properties in the Synthesis of N,N-Dimethylformamide and Methyl Formate from Supercritical Carbon Dioxide. J. Catal. 1998, 178, 284. [CrossRef]

52. Yang, S.; He, J. Heterogeneous asymmetric Henry-Michael one-pot reaction synergically catalyzed by grafted chiral bases and inherent achiral hydroxyls on mesoporous silica surface. Chem. Commun. 2012, 48, 10349. [CrossRef] [PubMed]

53. Shiju, N.R.; Alberts, A.H.; Khalid, S.; Brown, D.R.; Rothenberg, G. Mesoporous Silica with Site-Isolated Amine and Phosphotungstic Acid Groups: A Solid Catalyst with Tunable Antagonistic Functions for One-Pot Tandem Reactions. Angew. Chem. 2011, 123, 9789. [CrossRef] 